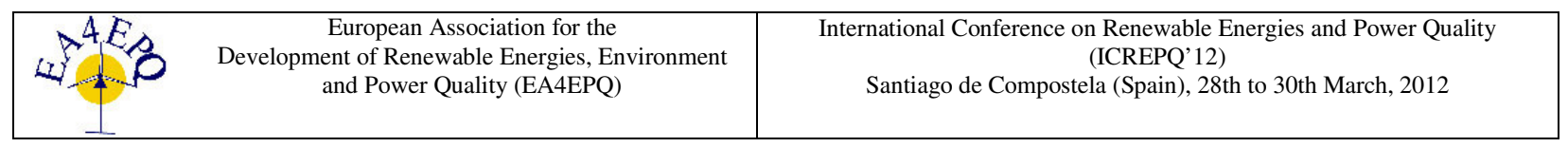

\title{
Performance measurements of car engine based MicroCHP test device
}

\author{
Dr. Péter Kádár, member of IEEE \\ Department of Power Systems \\ Óbuda University \\ Bécsi u. 94. Budapest H-1034 Hungary \\ Phone: +36 209447 241; fax: +30 1250 0940, e-mail: kadar.peter@kvk.uni-obuda.hu
}

\begin{abstract}
One of the most important features of the smart grid is the Dispersed/Distributed Generation. Natural Gas is widely used for small scale urban heating purposes. The individual households usually have $10-30 \mathrm{~kW}$ heating capacity boilers. The huge amount of burning gas is capable of electricity production. The microCHP (small scale Combined Heat and Power generation unit) has lot of advantages compared to the traditional gas boiler devices. In the next decade the spread of over millions of new microCHPs can be expected worldwide. This paper introduces the experimental petrol/Natural Gas /Propan Butan fueled CHP unit made from a second hand car engine and a squirrel cage induction motor. The machine we built is capable of demonstrating all measureable features such as efficiency, emission, active-reactive power control, speedup, etc. In the paper we introduce the role of the microCHP-s, the development of the test device and the metered values.
\end{abstract}

\section{Key words}

Keywords: induction motor - generator, small scale heating and dispersed electricity generation (CHP), multifuel, smart grid, second hand car engine

\section{The grid is smartening}

The Smart approach infiltrates into the existing grid, more and more smart solutions and devices will perform the future's smart operations. Beside other important features all the Smart definitions mention that this grid enables

- loads and distributed resources to participate in operations [7]

- large-scale deployment of DG (Distributed Generation) and renewable resources. [9]

There are some distributed electricity generation units that produce only electricity (PhotoVoltaics or Wind turbines), but there is a huge area where we produce a lot of energy waste permanently. That is the gas heating, where we produce only heat but electricity could be generated by the mechanical volume extension, too. The principle of the CHP (Combined Heat and Power generation) is

- first, the electricity generation (mainly on mechanic base internal combustion engines such as the micro-gas-turbine or the Otto engine. Electricity can be generated in fuel-cells [1],
Stirling engines or Rankine cycle engines, as well. [4])

- $\quad$ second, the usage of the heat of the exhaust gas

- A lot of bulk power plants (over $100 \mathrm{MW}$, mainly with gas turbine)

- medium category plants (0,5-3 MW mainly with multi cylinder gas engines).

operate according to this methodology.

The (bulk) CHP based electricity generation ratio was over $22 \%$ in Hungary in the year 2008. [8]

\section{The microCHP}

The CHP trend has spread over also in Europe and in the last decade the small scale microCHP (typically 1-10 kW) became commercially available. It can supply the individual households with heat and electricity, too.

In Germany 3,000 eco-power microCHP units have been installed, using the U.S. based Marathon Engine Systems long-life engine. [2] Furthermore over 23,000 DACHS mini-CHP units (typically $5,5 \mathrm{~kW}$ units) have been installed based on reciprocating engine technology. [3] Honda's $1 \mathrm{~kW}$ (electrical power) system - named Ecowill -is mainly used in single-family home applications. In Japan more than 30.000 units have been installed. [5] In Europe by the year 2020 over 10 million microCHPs are forecasted. For Central and Eastern Europe the installation potential is 700.000 units. [6] If we count an $1,5 \mathrm{~kW}$ average power per CHP and assume 10 million devices, it makes $15.000 \mathrm{MW}$, that is the $3,5 \%$ of the 400 GW operational power of the European system. This huge unit number can cooperate only as controlled "virtual power plants" that will be achieved by the Smart Grid philosophy.

\section{Energetic approach}

We are interested in the national energy efficiency. In a short calculation we compared the performance of the central electricity generation and the local heat production 
(gas heated boiler for heating purposes) with the distributed small CHP engines.

The up-to-date bulk Combined Cycle Gas Turbine (CCGT) power plants works with over $50 \%$ electrical efficiency.

The traditional gas boiler has $87 \%$ average heat efficiency. A typical microCHP has $26 \%$ electrical efficiency and $61 \%$ heat usage efficiency.

Table I. - Advantage of the microCHP

\begin{tabular}{|l|c|c|c|c|}
\hline & $\begin{array}{c}\text { USED } \\
\text { GAS } \\
\mathrm{m}^{3}\end{array}$ & $\begin{array}{c}\text { HEAT } \\
\text { MJ }\end{array}$ & $\begin{array}{c}\text { ELECTRI- } \\
\text { CITY MJ }\end{array}$ & $\begin{array}{c}\text { WASTE } \\
\text { HEAT MJ }\end{array}$ \\
\hline Gas boiler & 1 & 29,44 & & 4,56 \\
\hline CCGT & 0,42 & & $\mathbf{7 , 1 4}$ & 7,14 \\
\hline MicroCHP & 1,42 & 29,44 & $\mathbf{1 2 , 9 5}$ & 5,89 \\
\hline
\end{tabular}

The calculation shows that the small scale co-generation produces more electricity from the same input gas by heat constraint than the simple gas boiler and the separate good efficiency CCGT. This encourages us to investigate and foster the microCHP development. The energy performance analysis did not take into account the investment into the devices.

\section{Preparatory measurements}

Although every electrical machine course teaches the symmetrical torque-speed (slip) curve of the squirrel cage induction motor, in the laboratory mainly the motor quarter is investigated. For a test we investigated a squirrel cage induction motor in generator mode.

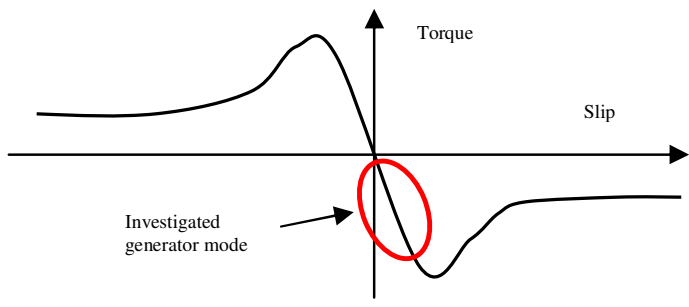

Fig. 1. Typical characteristics of a squirrel cage induction motor

We found that the characteristics meet the expectations. Of course, for the better exploitation of the magnetic saturation, an electrical machine is planned for motor or generator, and according to the equations it must operate.

\section{The test device}

In the last half decade the world's yearly car production was over 50 millions [10]. Roughly, this is the number of the cars withdrawn from circulation yearly, as well. Having seen the huge amount of industrial waste, we made a trial to use an old car engine to drive a 3 phase squirrel cage induction motor. Motor (not a generator) because it operated decades in a small plant, and we looked for a second hand device. The basic approach is:

- a large number of engines are available

- they are low cost

- it is a low speed operation

- $12 \mathrm{~V} \mathrm{DC}$ output is built in

- electrical efficiency is not so important for most of the heat waste is captured for heating purpose

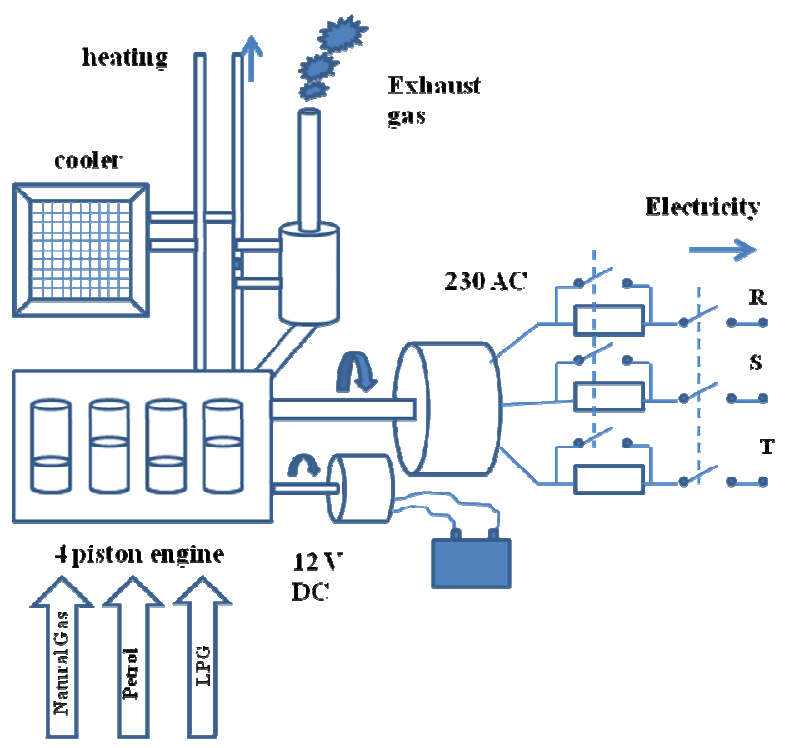

Fig. 2. The test microCHP system

We built a test microCHP with the following parameters:

- $\quad$ used car engine, former GDR produced Wartburg 1.3 VW-Engine, $43 \mathrm{~kW}$ (58 HP) for gasoline and LPG

- $\quad$ 7,5 kW 3 phase squirrel cage induction

- resistors for starting / synchronization

- connection to 3 phase $230 / 400 \mathrm{~V}$ AC $50 \mathrm{~Hz}$ utility network

- $12 \mathrm{~V} \mathrm{DC}$ battery for the self start and for DC output

The material cost of the devices was approx. 2000 USD. A new device's price in the same power range is over 20 thousand USD.

There are two ways of starting:

- Electrical start

- speeding up the squirrel cage induction motor with serial resistors (heating wire for iron)

- short circuiting the resistors when the synchronous-switch-condition's speed (1490 RPM) is reached

- $\quad$ ignition start of the engine

- $\quad$ pushing up the speed into the required power range (up to $1550 \mathrm{RPM}$ )

- Island start

- $\quad$ starting the engine

- $\quad$ speeding up to synchronous speed (1500 RPM)

- $\quad$ switching to the network through resistors (rough synchronization) 
- $\quad$ short circuiting the resistors

- $\quad$ speeding up to the wanted power

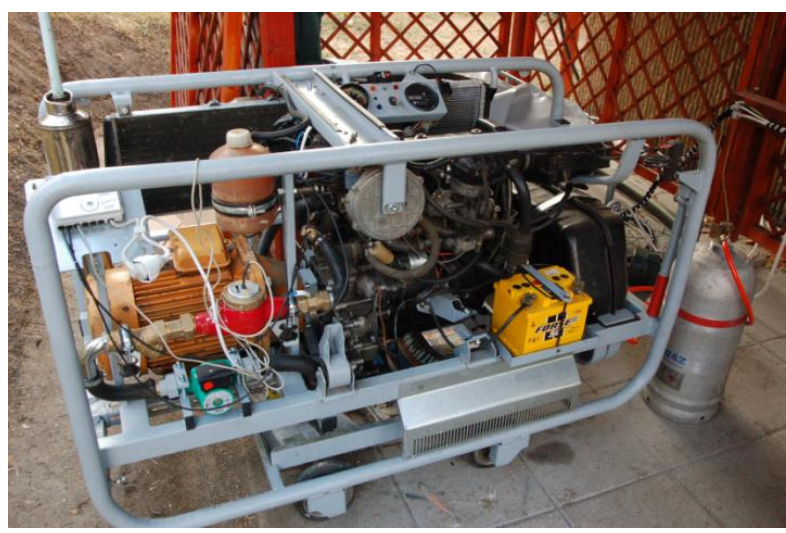

Fig. 3. The demonstrational microCHP during PB fuel operation

The first rough measurements brought the expected results. The output power is closely linear function of the speed.

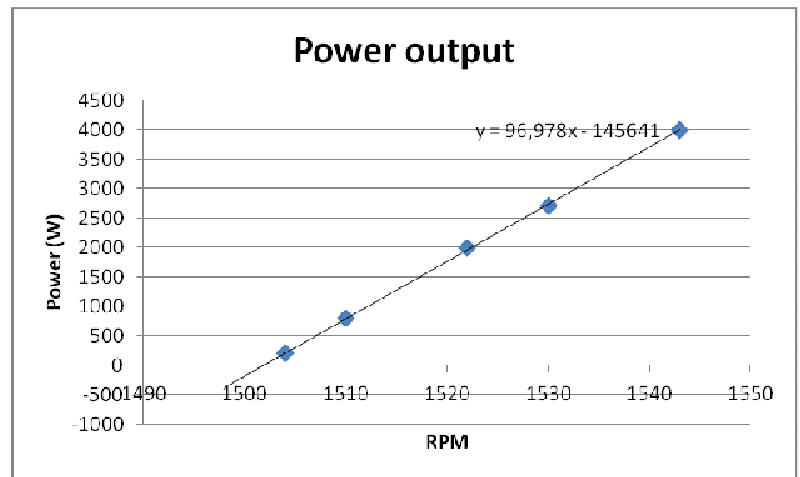

Fig. 4 . The 3 phase power fed back to the utility net

The comparative measurement between Propane/Butane fuel and petrol running resulted in higher efficiency for the gas.

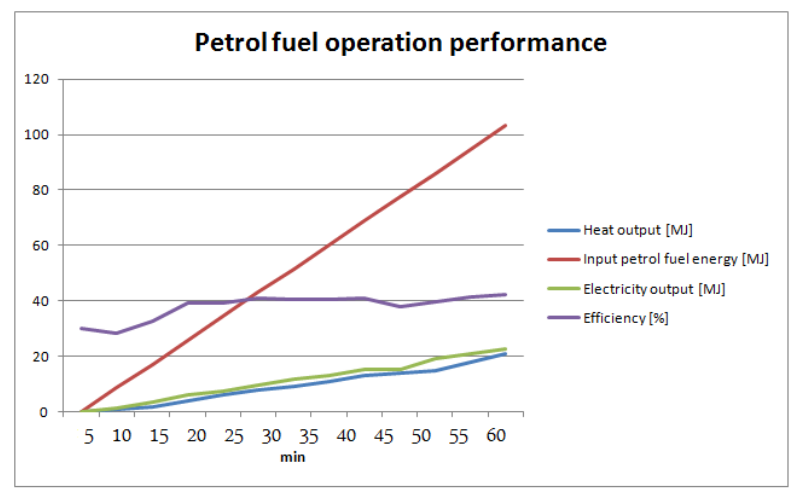

Fig. 5. Measurements of petrol operation

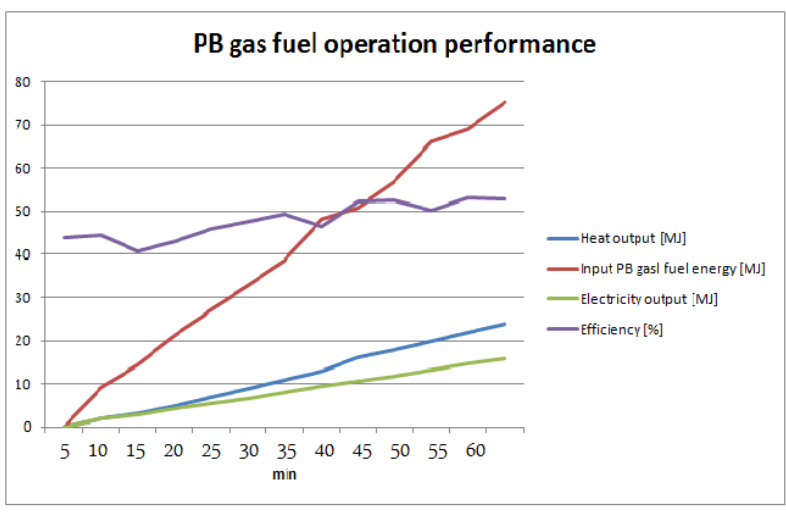

Fig. 6. Measurements of Propane/Butane fuel operation

The electrical measurements showed that an electronically not controlled "natural" induction motor consumed a lot of reactive power. In the following measurements we shall investigate the simple condenser compensation, the free run operation and the island mode start, too.

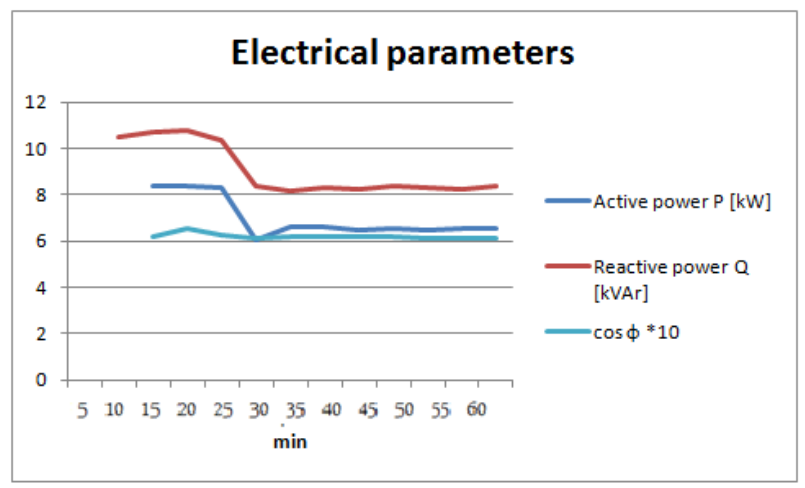

Fig. 7. Electrical data of 1 hour run

The thermal data were monitored by a Sontex Supercal 531 device, the energy fed back by a traditional Ferrariswheel energy meter.
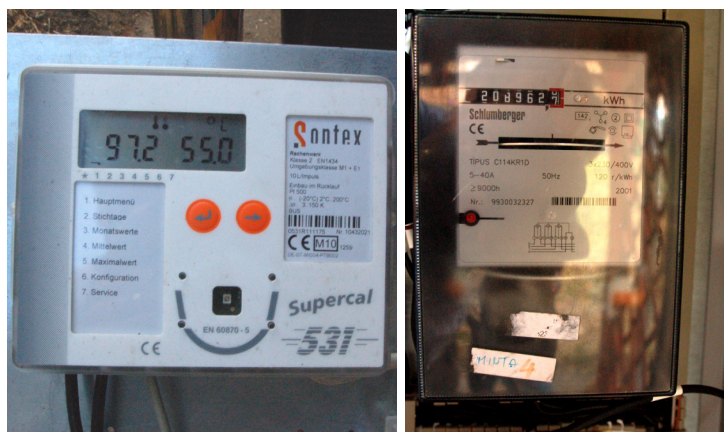

Fig.8. Heat and electricity metering 


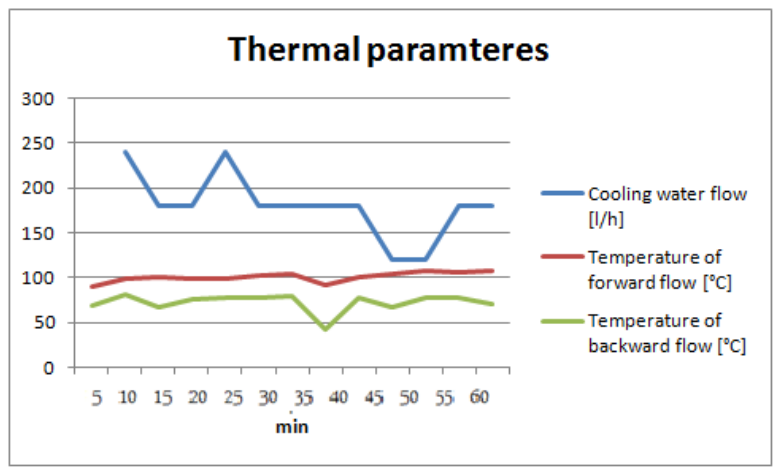

Fig.9. Thermal data of 1 hour run

The demonstration device operates but some questions are left open:

- emission control - in the future we are going to run this device by natural gas that limits the harmful emission. The CO content must be controlled.

- lubrication oil consumption

- long term operation - we have no long-term aging experiences, but the low speed (1500 RPM) spares the car engine (peak power about at $3500 \mathrm{RPM}$ )

Present development:

- Power regulation - in order to control the power output by the RPM (approx. 0-3\% of over speed) a fine speed control and stabilizer must be developed for the constant output. Also the over-speed protection functions must be solved in case of the load drop.

- Reactive power compensation - because we applied a squirrel cage induction motor, the internal voltage is over the nominal voltage so the machine's iron core can be closer to the magnetic saturation. This is one cause why our motor has relatively high reactive power consumption. The appropriate compensation method is under investigation.

- Appropriate heat isolating casing - the electrical efficiency has not a great importance, because the heat loss is used. The leaking heat must be caught by special coating and a cooling system.

- Remote control - the microCHP can operate as a member of the virtual power plant. That is why it must be remotely controlled or at least remotely started/stopped

\section{Conclusion}

By this solution we demonstrated that the spread over of the small scale microCHP was more than a promise of the far future. The CHP model can be built up by low cost industrial wastage elements. The system can be built by general motor mechanic's and electrician's know-how. In the future a program can be developed for the useful applications of the second hand car engines. It can be a real stage of the recycling between the operating car and the metal foundry amalgamation. In the future we shall investigate the application of biogas as fuel and also the potential cooperation of these devices in Smart environment.

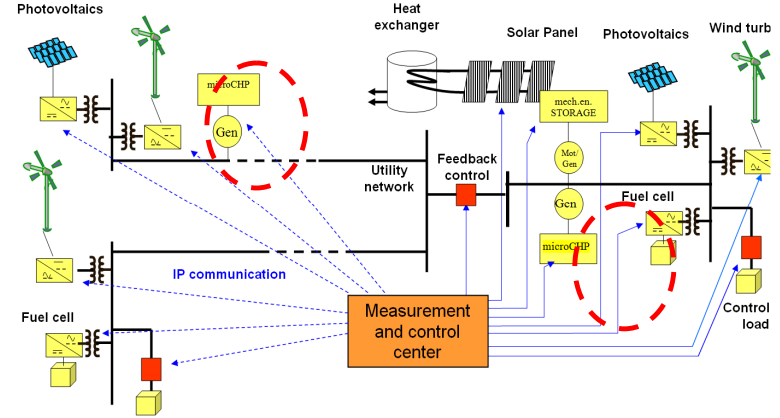

Fig.10. MicrCHP-s in Smart environment

\section{Acknowledgement}

We thank the laboratory measurement help of Zoltán Pálfi, professor of Óbuda University. The work was supported by Óbuda University Research Found no.: OERH-1105/-2011.

\section{References}

[1] Takahiro Kasuh, "Development strategies toward promotion and expansion of residential fuel cell micro-CHP system in Japan" http://www.igu.org/html/wgc2009/papers/docs/wgcFinal00 801.pdf

[2] http://en.wikipedia.org/wiki/Micro_combined_heat_and_po wer, 2009

[3] Senertec GmbH http://www.triecoenergy.com/chp.html

[4] Micro-CHP: Coming to a Home Near You? http://www.esource.com/esource/getpub/public/pdf/04Micr oCHPResultsFlyer.pdf

[5] State-of-the-art Micro CHP systems, Final report (EIE/04/252/S07.38608), Austrian Energy Agency, Vienna, March 2006

[6] Steve Ducker: MicroCHP market report, http://www.voltimum.co.uk/news/3826/s/MicroCHPmarket-report.html

[7] EPIC - SAIC: San Diego Smart Grid Study, Final Report, October

2006 , http://www.ilgridplan.org/Shared\%20Documents/San\%20D iego\% 20Smart\%20Grid\%20Study.pdf

[8] Energia Központ, http://www.evillamos.hu/nyomtat.php?id=1061 Key indices of electricity sales in the framework of feed-in obligation in 2010 http://www.eh.gov.hu/gcpdocs/201009/2010_1_kat_jelentes .pdf

[9] Will McNamara \& John Holt, The Utility of the Future KEMA - Perspectives and Observations http://emmos.org/prevconf/2009/Training\%20A\%20$\% 20 \mathrm{KEMA} \% 20 \mathrm{UoF} . \mathrm{pdf}$

[10] Cars produced in the world http://www.worldometers.info/cars/ by march 2011

[11] Veszprémi, K. - Lamár, K.: Accuracy Analysis of Digitally Implemented Field Orientation of Induction Motor Drive Proceedings of the 15th International Conference on Electrical Drives and Power Electronics EDPE'2003, Podbanské (Vysoké Tatry), Slovakia, pp.497-502. 2003. ISBN 808911445

[12] Lamár, K.: Inaccuracies in digitally controlled induction motor drives; Proceedings of the 21st Joint Scientific Conference "Science for Practice", Subotica, Serbia, pp. 3341. 2004. - ISBN 8685409039 